Supporting Information

\title{
A Dynamic Multimedia Environmental and Bioaccumulation Model for Brominated Flame Retardants in Lake Huron and Lake Erie, USA
}

\author{
Dong-Hee Lim and Christian M. Lastoskie ${ }^{*}$ \\ Department of Civil and Environmental Engineering, University of Michigan, \\ 1351 Beal Avenue, Ann Arbor, MI 48109-2125, USA
}

Email Address:

Dong-Hee Lim (limkr@umich.edu) and Christian M. Lastoskie (cmlasto@umich.edu)

* Corresponding author. Phone: (734) 647-7940. Fax: (734) 763-2275.

Journal Name: Environmental Toxicology and Chemistry

Total Number of Pages: 18 pages

Total Number of Figures: 8 (Figure S1 S8)

Total Number of Tables: 5 (Table S1 S5) 


\section{Modeling Methods}

\subsection{Fugacity-based multimedia environmental model}

The BFR mass balance equation for each compartment is as follows.

Air (subscript 1)

$$
V_{1} Z_{1} \frac{d f_{1}}{d t}=\left(E_{1}+G_{A 1} C_{B 1}+D_{21} f_{2}+D_{31} f_{3}\right)-f_{1}\left(D_{12}+D_{13}+D_{R 1}+D_{A 1}\right)
$$

Water (subscript 2)

$$
V_{2} Z_{2} \frac{d f_{2}}{d t}=\left(E_{2}+G_{A 2} C_{B 2}+D_{12} f_{1}+D_{32} f_{3}+D_{42} f_{4}\right)-f_{2}\left(D_{21}+D_{24}+D_{R 2}+D_{A 2}\right)
$$

Soil (subscript 3)

$$
V_{3} Z_{3} \frac{d f_{3}}{d t}=\left(E_{3}+D_{13} f_{1}\right)-f_{3}\left(D_{31}+D_{32}+D_{R 3}\right)
$$

Sediment (subscript 4)

$$
V_{4} Z_{4} \frac{d f_{4}}{d t}=\left(D_{24} f_{2}\right)-f_{4}\left(D_{42}+D_{R 4}+D_{A 4}\right)
$$

where $V$ represents the compartment volume $\left(\mathrm{m}^{3}\right), Z$ is the fugacity capacity $\left(\mathrm{mol} / \mathrm{m}^{3} \cdot \mathrm{Pa}\right), f$ is the fugacity $(\mathrm{Pa}), E$ is the emission rate $(\mathrm{mol} / \mathrm{h}), G$ is the advection flowrate $\left(\mathrm{m}^{3} / \mathrm{h}\right), C$ is the concentration $\left(\mathrm{mol} / \mathrm{m}^{3}\right)$, and $D$ is the $\mathrm{D}$-value $(\mathrm{mol} / \mathrm{Pa} \cdot \mathrm{h})$. Subscript $i j$ indicates transport from compartment $i$ to compartment $j$, and the subscripts $B, A$ and $R$ refer to the background concentration, advection, and reaction respectively.

Given initial conditions for the chemical concentration in each compartment, the evolving fugacities in the multimedia environment for a temporally varying emission profile is determined by numerical solution to the coupled set of first-order linear ordinary differential equations (S1S4). 


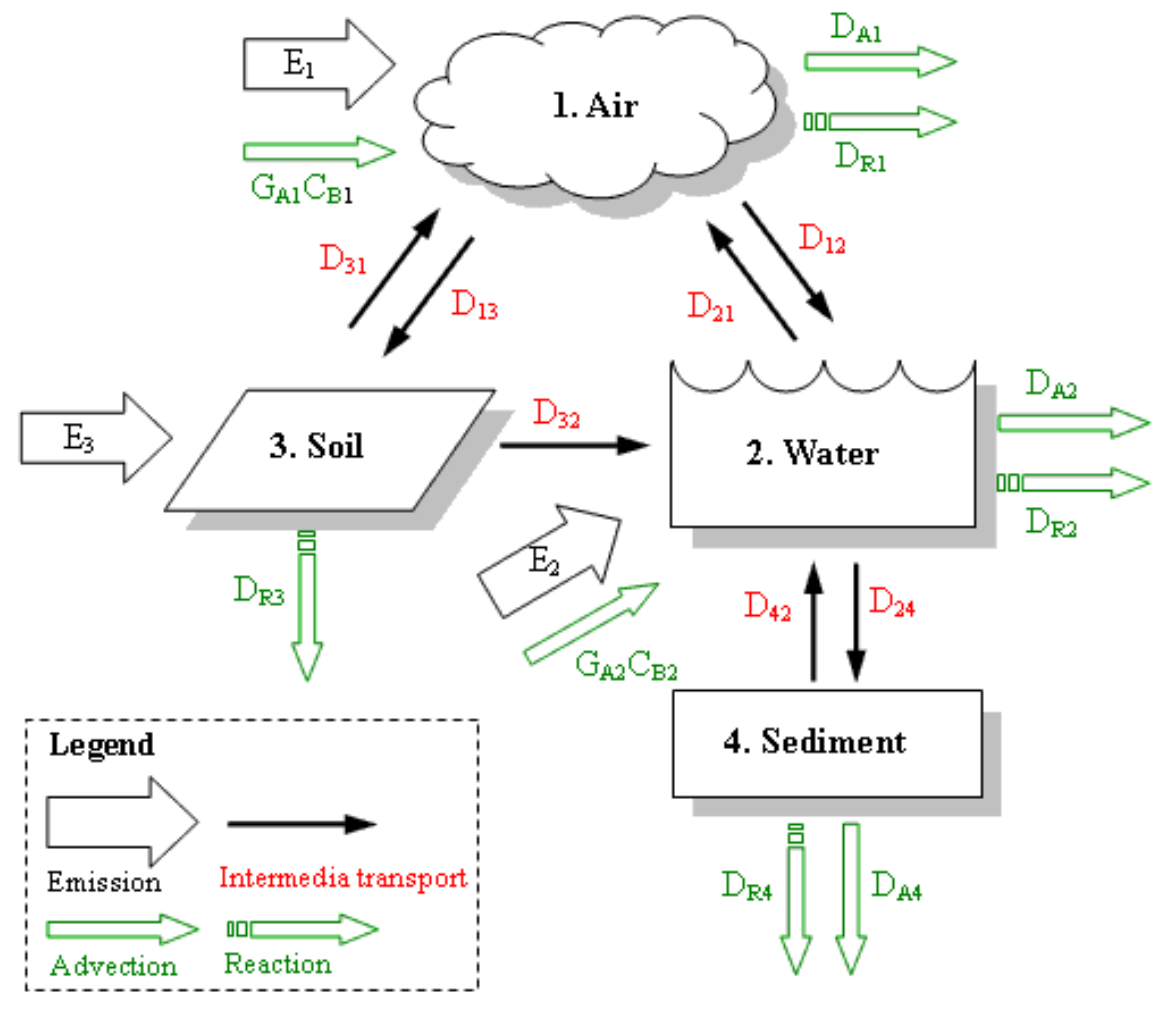

Figure S1. Schematic diagram of multimedia environmental compartment model. $E$ is the emission rate $(\mathrm{mol} / \mathrm{h}), G$ is the advection flow rate $\left(\mathrm{m}^{3} / \mathrm{h}\right), C$ is the concentration $\left(\mathrm{mol} / \mathrm{m}^{3}\right)$, and $D$ is the $\mathrm{D}$-value (mol/Pa.h). Subscript $i j$ indicates transport from compartment $i$ to compartment $j$, and the subscripts $B, A$ and $R$ refer to the background concentration, advection, and reaction respectively. 


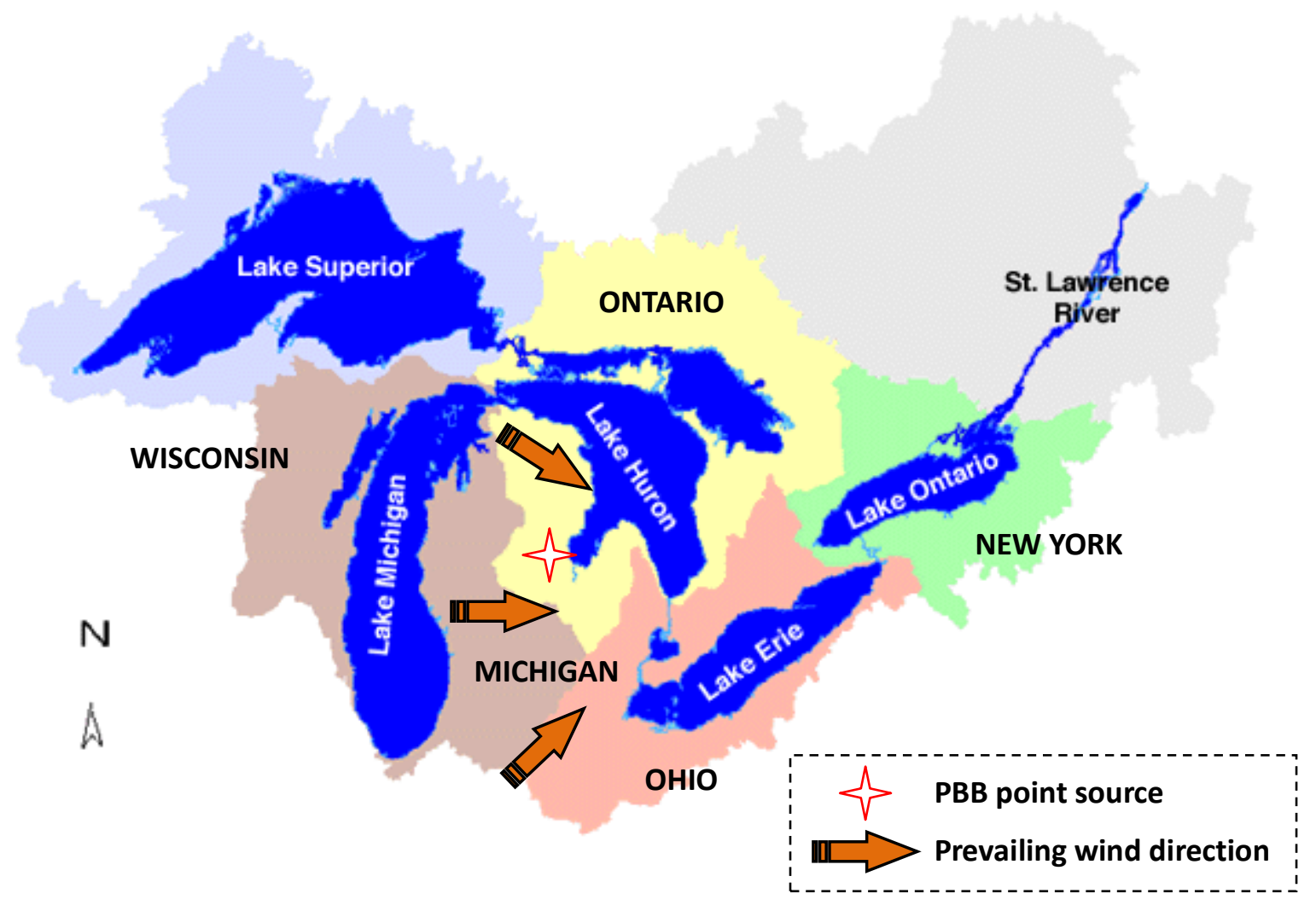

Note:

Figure is adapted from Reference [1].

Prevailing wind direction is obtained from Reference [2].

Figure S2. Great Lakes watersheds. The PBB point source is located in the Saginaw Bay region of Michigan. Arrows represent prevailing wind directions during the period from 19301996. 


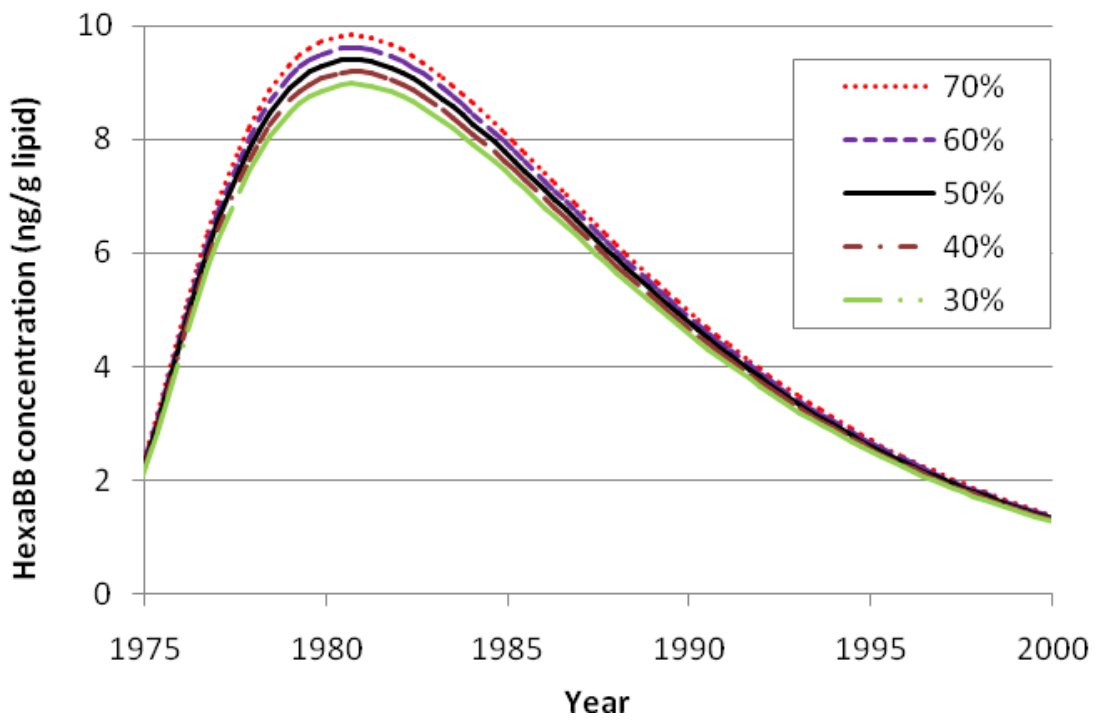

Figure S3. Comparison of model output for hexaBB concentration in Lake Erie lake trout, depending on the assumed fraction of air advection outflow of hexaBB from the Lake Huron watershed that enters the Lake Erie watershed as an air advection inflow.

Comment: In the PBB fate modeling study, $100 \%$ of the advection losses through the water and sediment compartments and $50 \%$ of the advection loss through the air compartment from the Lake Huron watershed were assumed to enter the Lake Erie watershed. This assumption is supported by the observation that prevailing wind directions in this region of the U.S. during the period from 1930 to 1996 are from the west-northwest (WNW) and west-southwest (WSW) in compass points [2] as shown in Figure S2.

Although the exact fraction of the PBB advection losses from the Lake Huron watershed that enters the Lake Erie watershed is unknown, as shown in Figure S3, the uncertainty in the hexaBB concentration in Lake Erie lake trout due to the choice of this fraction is less than 5.6\% within the fraction range from $70 \%$ to $30 \%$. This uncertainty is small in comparison to uncertainties associated with, for example, measurements of the observed hexaBB concentrations in lake trout. 


\subsection{Model inputs for landscape parameters, chemical properties, and food web properties}

The water solubility and vapor pressure of hexaBB at $25^{\circ} \mathrm{C}$ [3] were recalculated as $8.80 \times 10^{-4} \mathrm{~g} / \mathrm{m}^{3}$ and $5.54 \times 10^{-7} \mathrm{~Pa}$ respectively at the mean temperature of the study region, $8.6^{\circ} \mathrm{C}$, using the van't Hoff equation. No information was available for the half-life of hexaBB in fish, and so this parameter was set equal to the hexaBB degradation half-life in the fat tissue of rats [4]. Annual average concentrations of $\mathrm{PM}_{2.5}\left(9.4 \mu \mathrm{g} / \mathrm{m}^{3}\right)$ and the aerosol density $\left(1,800 \mathrm{~kg} / \mathrm{m}^{3}\right)$ were used to calculate the aerosol volume fraction in air [5, 6]. The air-side and water-side values of the air-water mass transfer coefficient (MTC) were calculated as suggested by Mackay and Yuen [7]. The air-side MTC depends on the average wind velocity, and for this parameter, Great Lake wind velocity data at $5 \mathrm{~m}$ height above the lake surface was used. Other MTCs were assigned using the default values for the Ontario, Canada region reported in ChemCAN Version 6.0 from the Canadian Centre for Environmental Modelling and Chemistry [8].

\subsection{Emission rate profile}

Evaporative emissions of PBDEs from principal reservoirs range from $0.01 \%$ to $0.7 \%$ [9]. Additionally, it is estimated that in the last two decades, $80 \%$ of the total reservoir of BFRs entered waste streams as municipal solid waste (MSW) [10]. Approximately $20 \%$ of the MSW was incinerated, and the remainder was disposed to landfill. Considering the structural and chemical similarities of PBBs and PBDEs [3], it is assumed that the evaporative emission factor of $\mathrm{PBB}$ products in use was $0.3 \%$, and that $80 \%$ of the total reservoir of PBBs entered the waste stream. To estimate evaporative losses of PBBs from products in use and from disposed consumer goods, it was further assumed that all PBB products produced in the U.S. were used in North America, and that the evaporative emissions within the study region were proportional to the populations in the selected areas, since PBBs were principally used as fire retardant additives for the thermoplastic casings of home electronic devices. (For the resident populations of Michigan and Ontario in the Great Lakes watersheds, the combined population of these two regions is about $3 \%$ of the total population of North America.) Also, air emissions of PBBs from waste incineration were assumed to be $0.01 \%$ of the landfill waste stream, and losses of PBBs by volatilization or leaching from non-incinerated landfill waste was presumed to be comparatively small and therefore negligible [9, 11]. Using these estimates, the non-point source PBB evaporative losses from in-use and discarded consumer goods were respectively computed as $0.17 \%$ and $0.001 \%$ of the total point-source PBB emissions from the Michigan Chemical Corporation manufacturing facility. The emission contributions from in-use and landfilled

products treated with PBBs were therefore small relative to direct PBB emissions from production, and are thus disregarded. 


\section{Results and Discussion}

\subsection{Pollutant contamination levels in Lake Erie}

The eastern part of Lake Erie shows relatively lower pollutant contamination levels compared to other parts of the Lake Erie. National Oceanic and Atmospheric Administration (NOAA) reported PBDE sediment concentrations along Lake Erie. The eastern part of Lake Erie showed the sediment concentrations ranging from 1 to $10 \mathrm{ppb}$ dry weight while the western part the sediment concentrations ranging from 11 to 88 ppb dry weight in 2004 [12]. Polychlorinated biphenyl (PCB) contamination in Lake Erie also indicates the similar trend as shown in the PBDE contamination. Figure S4 shows total PCB concentrations in sediment of Lake Erie in 1971 and 1995 (adapted from EPA [13]). The western part of Lake Erie shows relatively higher contamination than the eastern part of the lake. Painter et al. [14] also reported that the PCB sediment concentrations of the eastern part of Lake Erie were ranged from 0 to $35 \mathrm{ng} / \mathrm{g}$ while that of the western part ranged from 70 to 105 or over $105 \mathrm{ng} / \mathrm{g}$ in 1997 and 1998.

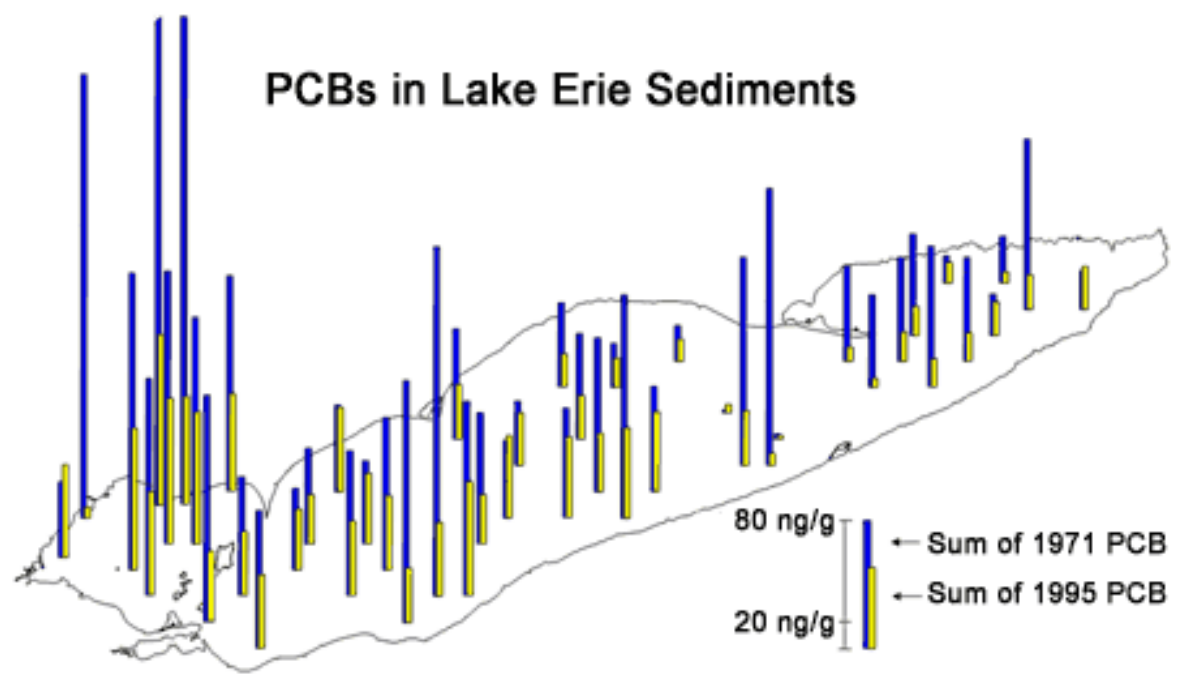

Note:

Figure is adapted from Reference [13]

Figure S4. Comparison of Lake Erie surficial sediment total PCB concentrations (ng/g dry wt.) in samples collected in 1971 and 1995. 


\subsection{Time trend of fugacities and PBB concentrations of aquatic organisms}

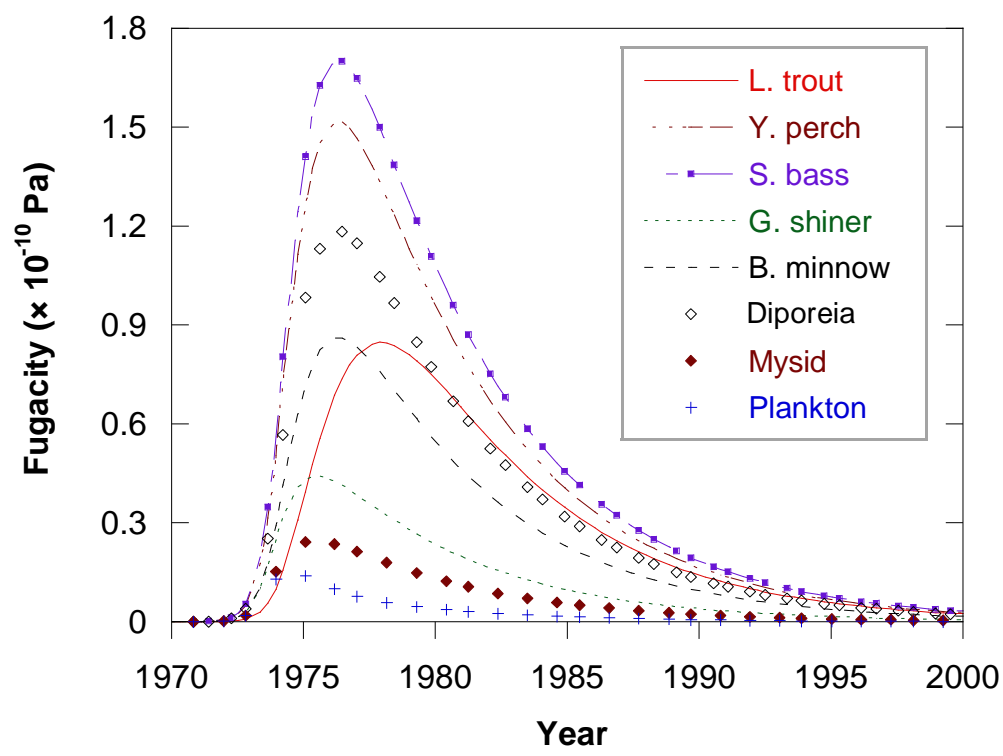

Figure S5. Time trend of fugacities of the aquatic organisms and sediment in the simulation of Lake Huron.

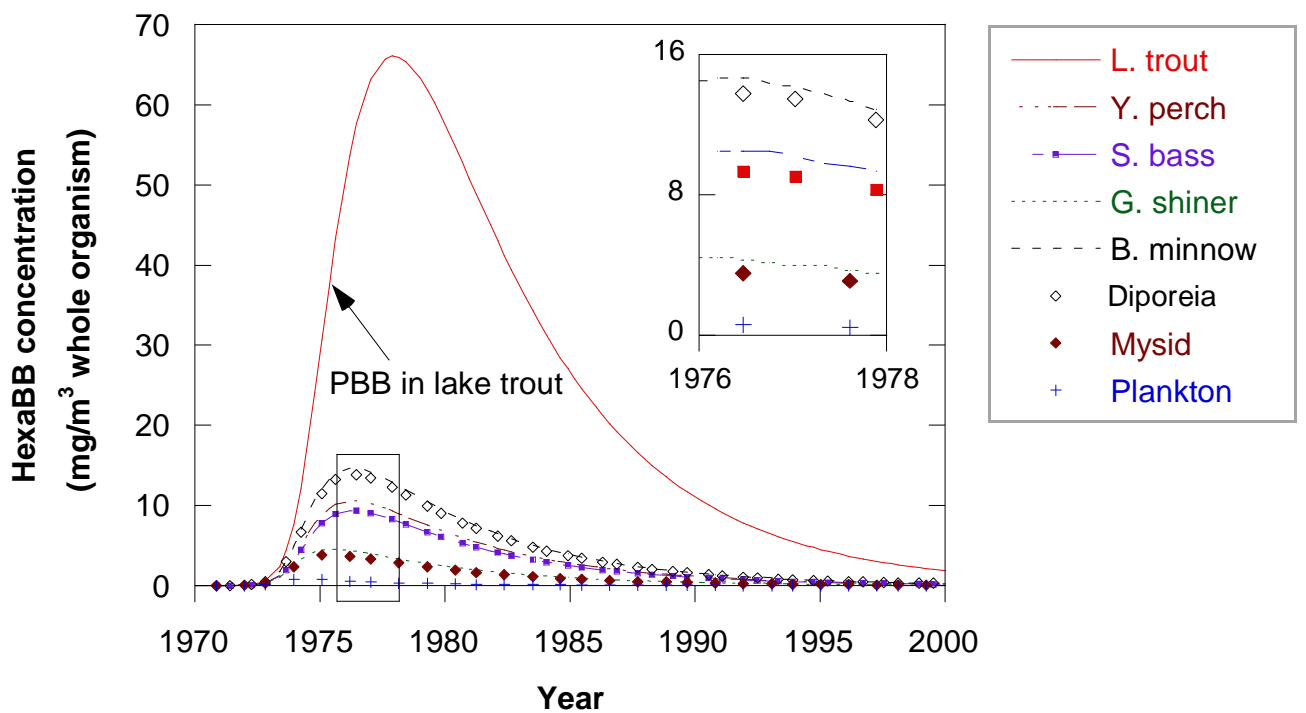

Figure S6. Time trend of hexaBB concentrations in the aquatic organisms and sediment fugacity in the simulation of Lake Huron. Detailed hexaBB concentration profiles of the organisms enclosed by a bold rectangle are shown in the right inset at the upper corner. 


\subsection{Estimation of BDE-47 emission by different emission scenarios}
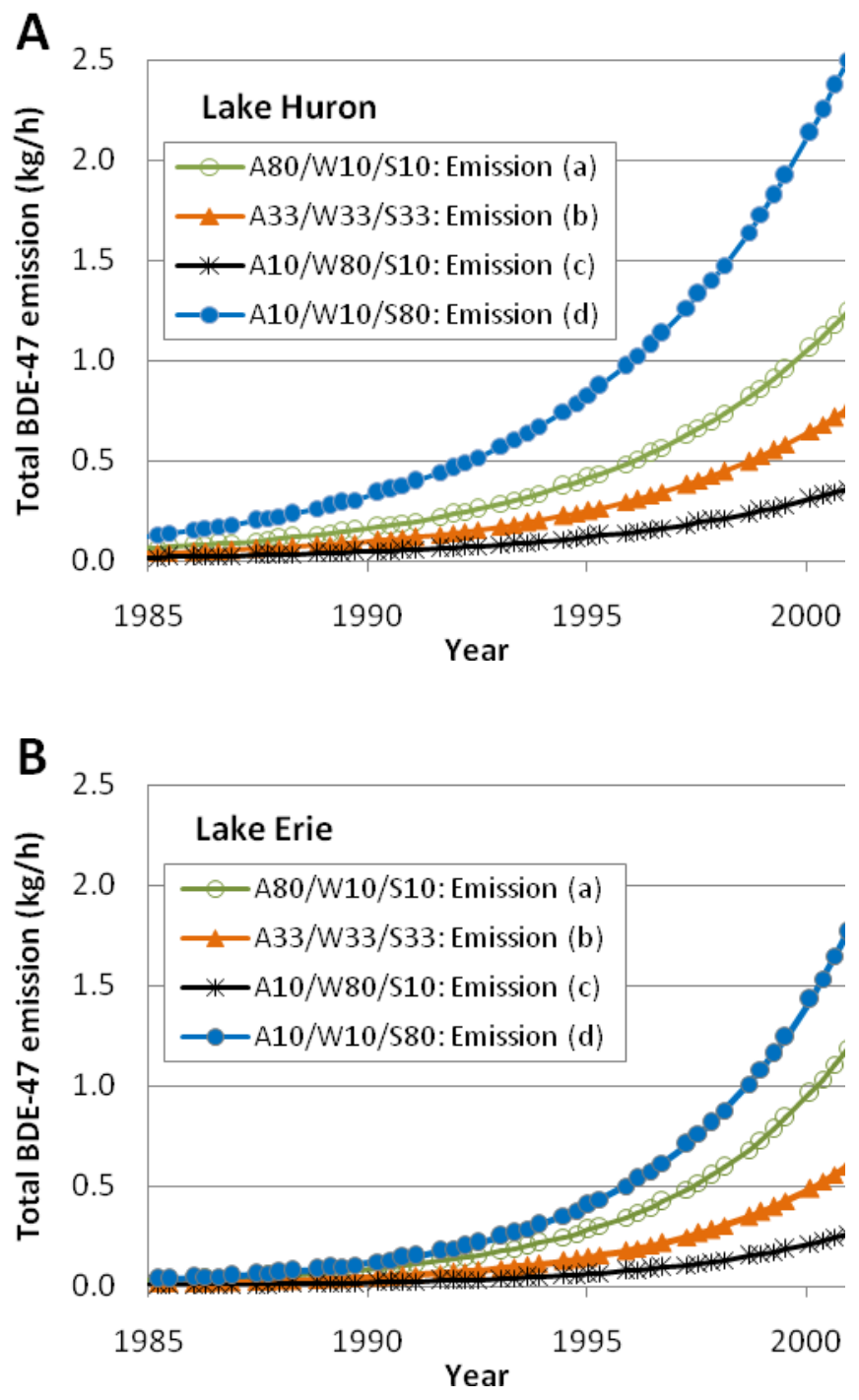

Figure S7. Estimation of total BDE-47 emission rates by different emission scenarios in Lake Huron (A) and Lake Erie (B). The legend indicates the percentage of the total BDE-47 emission released to air, water, and soil. For example, A80/W10/S10 refers to a scenario in which $80 \%$ of the BDE-47 emission is released to air, $10 \%$ is released to water, and $10 \%$ is emitted to soil. 


\subsection{Contribution fractions of emission sources to total BDE-47 emission into Lake Erie}
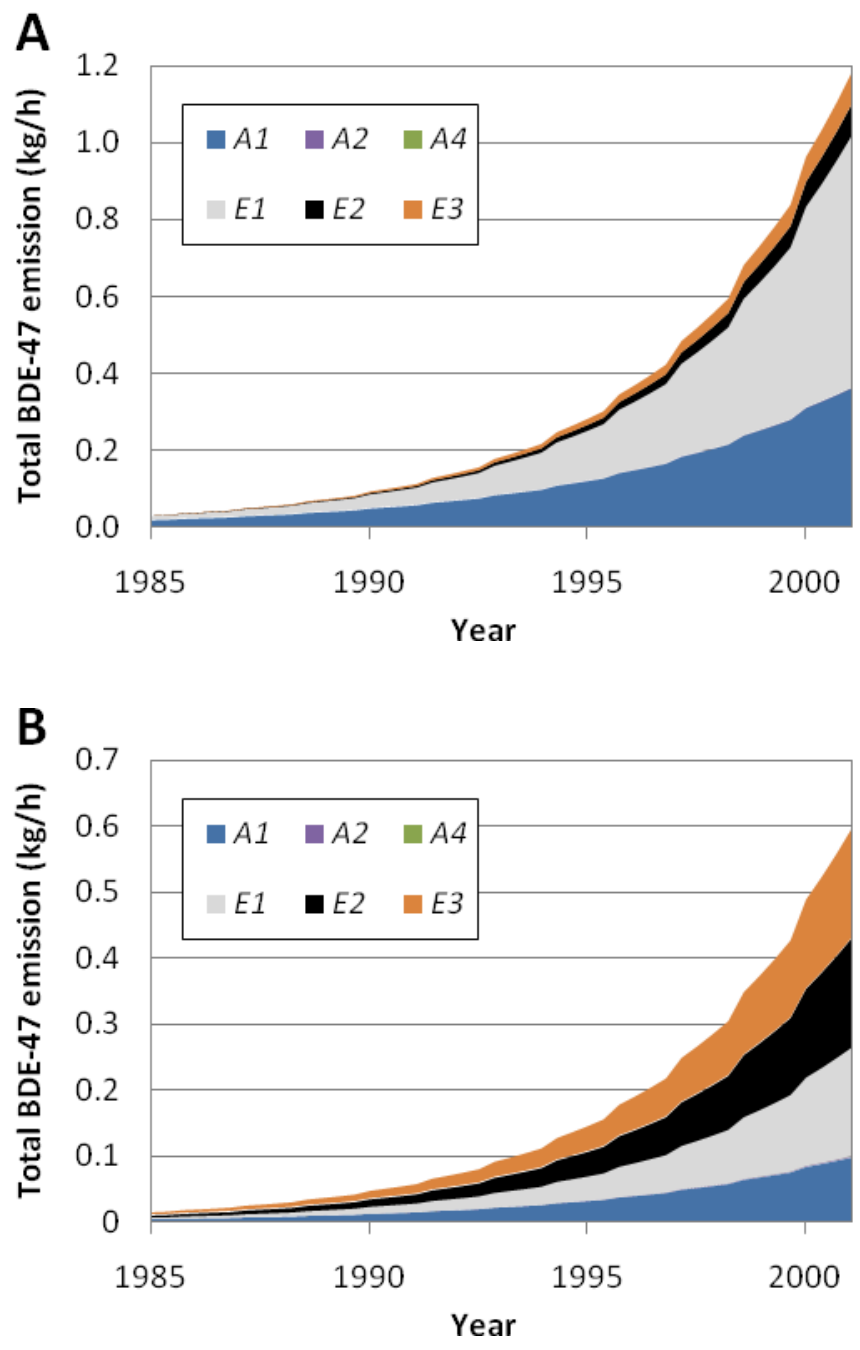

Figure S8. Input sources of BDE-47 into the Lake Erie watershed. $A$ and $E$ respectively represent advection input across the watershed boundary (by advective transfer from Lake Huron) and direct emission of BDE-47 from within the watershed boundary. Indices 1, 2, 3, and 4 refer to the air, water, soil, and sediment compartments, respectively. (A) Emission (a) scenario with BDE-47 emission into air (80\%), water (10\%), and soil (10\%); (B) Emission (b) scenario with BDE-47 emission equally divided into air, water, and soil (each $33.3 \%$ ).

Comment: In the case of the hexaBB fate modeling in which the point source of PBB is located in the watershed of Lake Huron, contaminant is directly delivered from the source into the each compartment of Lake Huron and is assumed to flow from the Lake Huron air, water, and sediment compartments to the corresponding media of Lake Erie. In the same model for the BDE-47 emission estimation, while the BDE-47 emission rate into Lake Huron is assumed to be only attributed to the direct emission from the Lake Huron's watershed area into the each 
compartment of Lake Huron, the emission rate into Lake Erie is assumed to be contributed by both the direct emission from Lake Erie's watershed and the advection inputs delivered from Lake Huron.

In both scenarios shown in Figure S8, the biggest BDE-47 input source to Lake Erie is direct emission from within the watershed boundary into the Lake Erie air compartment. Note that the direct emission reported for the air compartment of Lake Erie may include advection inputs originating from the adjacent areas of the Lake Erie watersheds. The contributed fraction of the advection inputs from the adjacent areas of Lake Erie was not explicitly considered in this model due to a lack of available data.

Similarly, in the case of Lake Huron, the total BDE-47 emission rate represents direct emission from within the Lake Huron watershed area in accordance with the assumed model structure. Although the total BDE-47 emission should include advection inputs from Lake Huron's neighboring watershed areas as well as direct emission from within the watershed boundary into the Lake Huron environmental compartments, the advection inputs were not explicitly considered in this model. Thus, we are unable to determine the contributed fractions of BDE-47 input from the advection inputs and from the direct emission for Lake Huron. 
Table S1. Environmental input parameters and transport velocities used in Level IV multimedia compartment model.

\begin{tabular}{|c|c|c|}
\hline Parameters & Lake Huron & Lake Erie \\
\hline Mean temperature $\left({ }^{\circ} \mathrm{C}\right)$ & $8.6^{a}$ & $8.6^{a}$ \\
\hline Air volume $\left(\mathrm{m}^{3}\right)$ & $1.93 \mathrm{E}+14^{b}$ & $1.04 \mathrm{E}+14^{b}$ \\
\hline Atmospheric height (m) & $1000^{c}$ & $1000^{c}$ \\
\hline Density $\left(\mathrm{kg} / \mathrm{m}^{3}\right)$ & $1.185^{d}$ & $1.185^{d}$ \\
\hline Wind velocity at $5 \mathrm{~m}$ height $(\mathrm{m} / \mathrm{s})$ & $5.45^{e}$ & $5.45^{e}$ \\
\hline Residence time (hr) & 22.4 & 16.4 \\
\hline Aerosol volume fraction & $5.218 \mathrm{E}-12^{f}$ & $5.218 \mathrm{E}-12^{f}$ \\
\hline Aerosol density $\left(\mathrm{kg} / \mathrm{m}^{3}\right)$ & $1800^{g}$ & $1800^{g}$ \\
\hline Aerosol dry deposition rates $(\mathrm{m} / \mathrm{h})$ & $1.804 \mathrm{E}+01^{c}$ & $1.804 \mathrm{E}+01^{c}$ \\
\hline Water volume $\left(\mathrm{m}^{3}\right)$ & $3.54 \mathrm{E}+12^{b}$ & $4.88 \mathrm{E}+11^{b}$ \\
\hline Depth $(\mathrm{m})$ & $59.4^{b}$ & $19.0^{b}$ \\
\hline Density $\left(\mathrm{kg} / \mathrm{m}^{3}\right)$ & $1000^{d}$ & $1000^{d}$ \\
\hline Residence time (hr) & $1.98 \mathrm{E}+05^{b}$ & $2.28 \mathrm{E}+04^{b}$ \\
\hline Aquatic biota fraction & $1.0 \mathrm{E}-06^{g, h}$ & $1.0 \mathrm{E}-6^{g, h}$ \\
\hline Aquatic biota lipid fraction & $0.05^{g, h}$ & $0.05^{g, h}$ \\
\hline Aquatic biota density $\left(\mathrm{kg} / \mathrm{m}^{3}\right)$ & $1000^{g, h}$ & $1000^{g, h}$ \\
\hline Water runoff $(\mathrm{m} / \mathrm{h})$ & $3.72 \mathrm{E}-05^{g}$ & $4.05 \mathrm{E}-05^{g}$ \\
\hline Soil volume $\left(\mathrm{m}^{3}\right)$ & $9.24 \mathrm{E}+09$ & $1.96 \mathrm{E}+10$ \\
\hline Depth $(\mathrm{m})$ & $0.25^{i}$ & $0.25^{i}$ \\
\hline Density $\left(\mathrm{kg} / \mathrm{m}^{3}\right)$ & Solid $(2400)^{g, h}$ & Solid $(2400)^{g, h}$ \\
\hline Organic carbon fraction & $0.02^{g, h}$ & $0.02^{g, h}$ \\
\hline Solid / air / water fraction & $0.5 / 0.2 / 0.3^{g, h}$ & $0.5 / 0.2 / 0.3^{g, h}$ \\
\hline Solids runoff $(\mathrm{m} / \mathrm{h})$ & $2.283 \mathrm{E}-08^{g, h}$ & $2.283 \mathrm{E}-08^{g, h}$ \\
\hline Sediment volume $\left(\mathrm{m}^{3}\right)$ & $5.96 \mathrm{E}+08$ & $2.57 \mathrm{E}+8$ \\
\hline Depth (m) & $0.01^{g, h}$ & $0.01^{g, h}$ \\
\hline Density $\left(\mathrm{kg} / \mathrm{m}^{3}\right)$ & Solid $(2400)^{g, h}$ & Solid $(2400)^{g, h}$ \\
\hline Organic carbon fraction & $0.04^{g, h}$ & $0.04^{g, h}$ \\
\hline Solid / water fraction & $0.3 / 0.7^{g, h}$ & $0.3 / 0.7^{g, h}$ \\
\hline Residence time (hr) & $9.90 \mathrm{E}+06^{h}$ & $1.14 \mathrm{E}+06^{h}$ \\
\hline Suspended Sediment fraction & $5.0 \mathrm{E}-6^{g, h}$ & $5.0 \mathrm{E}-6^{g, h}$ \\
\hline Suspended Sediment density $\left(\mathrm{kg} / \mathrm{m}^{3}\right)$ & $2400^{g, h}$ & $2400^{g, h}$ \\
\hline Suspended Sediment organic carbon fraction & $0.2^{g, h}$ & $0.2^{g, h}$ \\
\hline Sediment deposition rate & $4.57 \mathrm{E}-07^{g, h}$ & $4.57 \mathrm{E}-07^{g, h}$ \\
\hline Sediment resuspension rate & $1.14 \mathrm{E}-07^{g, h}$ & $1.14 \mathrm{E}-07^{g, h}$ \\
\hline Sediment net deposition (burial) & $3.43 \mathrm{E}-07^{g, h}$ & $3.43 \mathrm{E}-07^{g, h}$ \\
\hline Rain rate $(\mathrm{m} / \mathrm{h})$ & $9.30 \mathrm{E}-05^{g}$ & $1.01 \mathrm{E}-04^{g}$ \\
\hline Scavenging ratio (dimensionless) & 200000 & 200000 \\
\hline \multicolumn{3}{|l|}{ Transport velocities $(\mathrm{m} / \mathrm{h})$} \\
\hline Air side air-water MTC $^{j}$ & 41.85 & 41.85 \\
\hline Water side air-water MTC & 0.0801 & 0.0801 \\
\hline Soil-air phase diffusion MTC & $0.04^{k}$ & $0.04^{k}$ \\
\hline Soil-water phase diffusion MTC & $1.00 \mathrm{E}-05^{k}$ & $1.00 \mathrm{E}-05^{k}$ \\
\hline Soil-air boundary layer MTC & $1.0^{k}$ & $1.0^{\mathrm{k}}$ \\
\hline Sediment-water diffusion MTC & $1.00 \mathrm{E}-04^{k}$ & $1.00 \mathrm{E}-04^{k}$ \\
\hline \multicolumn{3}{|c|}{$\begin{array}{l}{ }^{a} \text { Reference [15]; }{ }^{b} \text { Reference [16]; }{ }^{c} \text { Reference [17]; }{ }^{d} \text { Reference [18]; }{ }^{e} \text { Reference [19]; } \\
{ }^{f} \text { Reference [5]; }{ }^{g} \text { Reference [6]; }{ }^{j} \text { Reference [20]; }{ }^{i} \text { Reference [21]; }\end{array}$} \\
\hline
\end{tabular}


Table S2. Physicochemical properties and degradation half-lives of hexabromobiphenyl ${ }^{a}$ and tetrabromodiphenyl ether ${ }^{b}$.

\begin{tabular}{|c|c|c|}
\hline Characteristics & $\begin{array}{l}\text { Hexabromobiphenyl } \\
\text { (HexaBB) }\end{array}$ & $\begin{array}{c}\text { Tetrabromodiphenyl ether } \\
\text { (BDE-47) }\end{array}$ \\
\hline Synonym(s) & $\begin{array}{l}\text { FireMaster BP-6 } \\
\text { FireMaster FF-1 }\end{array}$ & \\
\hline Chemical formula & $\mathrm{C}_{12} \mathrm{H}_{4} \mathrm{Br}_{6}$ & $\mathrm{C}_{12} \mathrm{H}_{6} \mathrm{Br}_{4} \mathrm{O}$ \\
\hline Molecular weight & 627.4 & 485.8 \\
\hline Melting point & $72{ }^{\circ} \mathrm{C}$ & $84.1^{\circ} \mathrm{C}$ \\
\hline Water Solubility & $\begin{array}{l}\left.1.10 \mathrm{E}-02 \mathrm{~g} / \mathrm{m}^{3} \text { (at } 25^{\circ} \mathrm{C}\right) \\
\left.8.80 \mathrm{E}-04 \mathrm{~g} / \mathrm{m}^{3} \text { (at } 8.6^{\circ} \mathrm{C}\right)\end{array}$ & $\begin{array}{l}9.47 \mathrm{E}-02 \mathrm{~g} / \mathrm{m}^{3}\left(\text { at } 25^{\circ} \mathrm{C}\right) \\
1.03 \mathrm{E}-02 \mathrm{~g} / \mathrm{m}^{3}\left(\text { at } 8.6^{\circ} \mathrm{C}\right)\end{array}$ \\
\hline Log Kow & 6.39 & 6.39 \\
\hline Vapor pressure & $\begin{array}{l}\left.\text { 6.93E-06 Pa (at } 25^{\circ} \mathrm{C}\right) \\
5.54 \mathrm{E}-07 \mathrm{~Pa}\left(\text { at } 8.6^{\circ} \mathrm{C}\right)\end{array}$ & $\begin{array}{l}\left.\text { 2.15E-04 Pa (at } 25^{\circ} \mathrm{C}\right) \\
2.33 \mathrm{E}-05 \mathrm{~Pa}\left(\text { at } 8.6^{\circ} \mathrm{C}\right)\end{array}$ \\
\hline Henry's law constant & $0.395 \mathrm{~Pa} \cdot \mathrm{m}^{3} / \mathrm{mol}$ & $1.099 \mathrm{~Pa} \cdot \mathrm{m}^{3} / \mathrm{mol}$ \\
\hline \multicolumn{3}{|c|}{ Degradation Half-lives of hexabromobiphenyl (units: hours) ${ }^{c}$} \\
\hline Air & 906 & 256 \\
\hline Water & 4,320 & 3,600 \\
\hline Soil & 8,640 & 3,600 \\
\hline Sediment & 38,900 & 14,400 \\
\hline Fish (Fat) & $11,592^{d}$ & $1,000^{e}$ \\
\hline
\end{tabular}

\footnotetext{
${ }^{a}$ Reference [3].

${ }^{b}$ Reference [22].

${ }^{c}$ Estimated by EPIWIN software provided by U.S. Environmental Protection Agency [23].

${ }^{d}$ Reference [4] (assumed based on the biological half-life of FireMaster BP-6 in rat fat).

${ }^{e}$ Reference [24].
} 
Table S3. Aquatic organisms and their properties used in the bioaccumulation model in food webs of Lake Huron and Lake Erie.

\begin{tabular}{lrrrrrrrrrr}
\hline \multicolumn{1}{c}{ Species } & $\begin{array}{c}\text { Vol } \\
\left(\mathbf{c m}^{3}\right)\end{array}$ & \multicolumn{1}{c}{$\mathbf{L F}^{a}$} & $\mathbf{Q D}^{b}$ & $\mathbf{T M D}^{\boldsymbol{c}}$ & $\mathbf{G R R D}^{d}$ & $\mathbf{G I P V}^{\boldsymbol{c}}$ & $\mathbf{G A O}^{f}$ & $\mathbf{G A W}^{g}$ & $\mathbf{X W}^{h}$ & $\mathbf{X S}^{i}$ \\
\hline (1) Plankton & 0.0005 & 0.015 & 3 & 500,000 & 0.025 & 0 & 4 & $5.3 \mathrm{E}-8$ & 1 & 0 \\
(2) Mysid & 0.1 & 0.04 & 3 & 50,000 & 0.02 & 20 & 3.5 & $5.3 \mathrm{E}-8$ & 1 & 0 \\
(3) Diporeia & 0.002 & 0.03 & 3 & 50,000 & 0.02 & 0 & 4 & $5.3 \mathrm{E}-8$ & 0 & 1 \\
(4) Bluntnose minnow & 30.0 & 0.0435 & 3 & 5,000 & 0.005 & 4 & 1.5 & $5.3 \mathrm{E}-8$ & 1 & 0 \\
(5) Golden shiner & 49.8 & 0.0265 & 3 & 5,000 & 0.005 & 4 & 1.5 & $5.3 \mathrm{E}-8$ & 1 & 0 \\
(6) Smallmouth bass & 1474 & 0.0141 & 3 & 5,000 & 0.004 & 3.5 & 1.5 & $5.3 \mathrm{E}-8$ & 1 & 0 \\
(7) Yellow perch & 312 & 0.0179 & 3 & 5,000 & 0.005 & 4 & 1.5 & $5.3 \mathrm{E}-8$ & 1 & 0 \\
(8) Lake trout & 2346 & 0.2 & 3 & 5,000 & 0.002 & 2 & 1.2 & $5.3 \mathrm{E}-8$ & 1 & 0 \\
\hline
\end{tabular}

${ }^{a}$ LF: lipid volume fraction.

${ }^{b}$ QD: digestion factor.

${ }^{c}$ TMD: metabolic half-life (days).

${ }^{d}$ GRRD: growth rate (fraction of volume per day).

${ }^{e}$ GIPV: feeding rate (percent of body mass per day).

${ }^{f}$ GAO: gut absorption efficiency parameter (organic).

${ }^{g}$ GAW: gut absorption efficiency parameter (water).

${ }^{h} \mathrm{XW}$ : fraction of respiration from water.

${ }^{i} \mathrm{XS}$ : fraction of respiration from sediment.

Reference for Vol and LF of species (1 3): obtained from FoodWeb Model [8]

Reference for Vol of species (4 \& 5) and LF of species (4 7): obtained from Reference [25]

Reference for Vol of species (6 \& 7): obtained from Reference [26].

Reference for Vol and LF of species (8): obtained from Reference [27].

Reference for $\mathrm{b} \sim \mathrm{i}$ : obtained from Reference $[8,28]$.

\section{Note:}

Suspended solid concentration

$=$ SuspendedParticle Fraction $\left(5 \times 10^{-6}\right) \times$ SuspendedParticle Density $\left(2400 \mathrm{~kg} / \mathrm{m}^{3}\right)=12 \mathrm{~g} / \mathrm{m}^{3}$

Fraction of organic carbon content on suspended solids in the water $=0.2$ 
Table S4. PBB production amount in Michigan from 1970 to 1974.

\begin{tabular}{rr}
\hline Year & Production $(\mathbf{k g})$ \\
\hline 1970 & 9,480 \\
1971 & 83,916 \\
1972 & $1,007,446$ \\
1973 & $1,764,050$ \\
1974 & $2,214,475$ \\
$1975^{a}$ & 262,188 \\
$1976^{a}$ & 8,193 \\
$1977^{a}$ & 2,731 \\
Total $^{a}$ & $\mathbf{5 , 3 5 2 , 4 8 0}$ \\
\hline
\end{tabular}

${ }^{a}$ The production amounts in 1975, 1976, and 1977 were assumed $96 \%, 3 \%$, and $1 \%$, respectively, of the discrepant amount between the total production from 1970 to 1977 and the sum of total annual productions from 1970 to 1974 . These percentages were estimated based on ratios of PBB loading discharged to the Pine River by Michigan Chemical Corporation, Michigan [29]

Table S5. Standard deviations of lognormal distributions for degradation half-lives of hexaBB. Numbers in parentheses under each compartment are degradation half-lives of hexaBB used as medians in the lognormal distributions.

\begin{tabular}{lccccc}
\hline & $\begin{array}{c}\text { Air } \\
(906 \mathrm{hrs})\end{array}$ & $\begin{array}{c}\text { Water } \\
(4,320 \mathrm{hrs})\end{array}$ & $\begin{array}{c}\text { Soil } \\
(8,640 \mathrm{hrs})\end{array}$ & $\begin{array}{c}\text { Sediment } \\
(38,900 \mathrm{hrs})\end{array}$ & Note \\
\hline$C f=2$ & 362 & 1,728 & 3,456 & 15,560 & median $\times 0.4$ \\
$C f=5$ & 1,268 & 6,048 & 12,096 & 54,460 & median $\times 1.4$ \\
$C f=10$ & 3,080 & 14,688 & 29,376 & 132,260 & median $\times 3.4$ \\
\hline
\end{tabular}




\section{REFERENCES}

[1] Great Lakes' Watershed and Islands. Lansing, MI, USA.

http://www.geo.msu.edu/geogmich/watershed.html.

[2] National Climatic Data Center (NCDC). Climatic Wind Data for the United States (November 1998). Asheville, NC, USA. http://www.ncdc.noaa.gov/oa/ncdc.html.

[3] Department of Health and Human Services, Public Health Service Agency for Toxic Substances and Disease Registry. 2004. Toxicological Profile for Polybrominated Biphenyls and Polybrominated Diphenylethers. Atlanta, GA, USA. http://www.atsdr.cdc.gov/ToxProfiles/tp.asp?id=901\&tid=183

[4] Miceli JN, Marks BH. 1981. Tissue distribution and elimination kinetics of polybrominated biphenyls (PBB) from rat-tissue. Toxicology Letters 9:315-320.

[5] State of Michigan, Department of Environmental Quality. 2003. Michigan's 2003 Annual Air Quality Report. Lansing, MI, USA.

http://www.michigan.gov/documents/deq/deq-aqd-air-reports-03AQReport_271761_7.pdf

[6] Zhang QO, Crittenden JC, Shonnard D, Mihelcic JR. 2003. Development and evaluation of an environmental multimedia fate model CHEMGL for the Great Lakes region. Chemosphere 50:1377-1397.

[7] Mackay D, Yeun ATK. 1983. Mass-transfer coefficient correlations for volatilization of organic solutes from water. Environ Sci Technol 17:211-217.

[8] The Canadian Centre for Environmental Modelling and Chemistry. 2003. ChemCAN Version 6.00. Peterborough, ON, Canada. http://www.trentu.ca/academic/aminss/envmodel/models/models.html.

[9] Alcock RE, Sweetman AJ, Prevedouros K, Jones KC. 2003. Understanding levels and trends of BDE-47 in the UK and North America: an assessment of principal reservoirs and source inputs. Environment International 29:691-698.

[10] U.S. Environmental Protection Agency (EPA). 1998 Update. Characterization of Municipal Solid Waste in the United States. EPA 530. Washington, DC, USA. http://www.epa.gov/osw/nonhaz/municipal/pubs/98charac.pdf

[11] Danish Environmental Protection Agency (EPA). 1999. Brominated Flame RetardantsSubstance Flow Analysis and Assessment of Alternatives. Environmental Project Nr. 494. Denmark. http://www.indymedia.org/media/2009/07/926988.pdf

[12] Kimbrough KL, Johnson WE, Lauenstein GG, Christensen JD, Apeti DA. 2009. An assessment of polybrominated diphenyl ethers (PBDEs) in sediments and bivalves of the U.S. coastal zone. National Oceanic and Atmospheric Administration (NOAA), Silver Spring, MD. 
[13] Hartig JH, Zarull MA, Ciborowski JJH, Gannon JE, Wilke E, Norwood G, and Vincent A. 2007. State of the Strait: Status and Trends of Key Indicators. ISSN 1715-398. Great Lakes Institute for Environmental Research, Occasional Publication No. 5, University of Windsor, Ontario, Canada.

[14] Painter S, Marvin C, Rosa F, Reynoldson TB, Charlton MN, Fox M, Thiessen L, Estenik JF. 2001. Sediment contamination in Lake Erie: A 25-year retrospective analysis. Journal of Great Lakes Research 27:434-448.

[15] National Data Buoy Center. Air and sea temperatures of Station 45003 and 45008 in Lake Huron (1980 2001). Stennis Space Center, MS, USA. http://www.ndbc.noaa.gov/.

[16] State of Michigan, Department of Environmental Quality,. 2002. Lake Huron Initiative Action Plan. Lansing, MI, USA.

[17] Zhong SY, In HJ, Bian XD, Charney J, Heilman W, Potter B. 2005. Evaluation of realtime high-resolution MM5 predictions over the Great Lakes region. Weather and Forecasting 20:63-81.

[18] Mackay D. 2001. Multimedia Environmental Models: The Fugacity Approach, 2nd ed. Lewis Publishers, Boca Raton.

[19] National Data Buoy Center. Wind speed of Station 45003 and 45008 in Lake Huron (1980 2001). Stennis Space Center, MS, USA. http://www.ndbc.noaa.gov/

[20] Mackay D, Paterson S. 1991. Evaluating the multimedia fate of organic chemicals: a Level III fugacity model. Environ Sci Technol 25:427-436.

[21] McKone TE, Layton DW. 1986. Screening the potential risks of toxic-substances using a multimedia compartment model - estimation of human exposure. Regulatory Toxicology and Pharmacology 6:359-380.

[22] Wania F, Dugani CB. 2003. Assessing the long-range transport potential of polybrominated diphenyl ethers: A comparison of four multimedia models. Environmental Toxicology and Chemistry 22:1252-1261.

[23] U.S. Environmental Protection Agency (EPA). 2007. EPI Suite ${ }^{\mathrm{TM}}$. Washington, DC. http://www.epa.gov/oppt/exposure/.

[24] Bhavsar SP, Gandhi N, Gewurtz SB, Tomy GT. 2008. Fate of PBDEs in juvenile lake trout estimated using a dynamic multichemical fish model. Environ Sci Technol 42:3724-3731.

[25] Blasland, Bouck \& Lee, INC., Quantitative Environmental Analysis, LLC. 2003. Housatonic River - Rest of River RCRA Facility Investigation Report (Section 6). Pittsfield, MA, USA. http://www.epa.gov/ne/ge/thesite/restofriver-reports.html

[26] Wisconsin Sea Grant. 2010. The Fish of Lake Huron. Madison, WI, USA. http://www.seagrant.wisc.edu/greatlakesfish/LakeHuron.html. 
[27] Luross JM, Alaee M, Sergeant DB, Cannon CM, Whittle DM, Solomon KR, Muir DCG. 2002. Spatial distribution of polybrominated diphenyl ethers and polybrominated biphenyls in lake trout from the Laurentian Great Lakes. Chemosphere 46:665-672.

[28] Campfens J, MacKay D. 1997. Fugacity-based model of PCB bioaccumulation in complex aquatic food webs. Environ Sci Technol 31:577-583.

[29] Hesse JL, Powers RA. 1978. Polybrominated biphenyl (PBB) contamination of Pine river, Gratiot, and Midland counties, Michigan. Environmental Health Perspectives 23:19-25. 